\title{
Discovering your teaching style
}

\author{
Seven ways to enhance your classroom presence
}

\author{
by Jeanine Akers
}

I n January 2000, I walked into Randall Library's instruction lab at the University of North Carolina-Wilmington to teach my first professional information literacy instruction session. As a reference librarian, I expected that I'd be responsible for teaching some classes, but, like many others, my graduate school education had provided only a smattering of training on teaching in a classroom setting. As a student, I'd done a field study where I assisted with many classes and even taught a couple on my own, but even with that experience I had not yet become an effective instructor.

Recent studies have shown that instruction has become an important component in many academic library public service positions. ${ }^{1}$ However, it is also true that not all schools of library and information science offer courses on topics related to instruction. $^{2}$

Furthermore, effective teaching is not a skill that can be learned through the coursework of one semester, but it is an ability that is crafted through an ongoing and evolving process.

As a librarian new to teaching, I was often frustrated by how little I seemed to accomplish in 50-minute instructional sessions. There were several early classroom flops during which carefully planned sessions were ru- ined by my cracking voice and nervous hives. Along the way, I realized that preparation and knowledge were only half the teaching battle. To be an effective teacher, one must develop his or her own instructional style.

A variety of teaching and learning experiences have helped me to discover and create my own style over the past few years. Now, much more comfortable and natural in front of a group, I have found that I teach best when I can blend personal interaction, lecture, and active learning exercises. When I do this, my sessions are much more effective and productive.

While this approach works for me, librarians should seek opportunities that will help them uncover and create their personal style in the classroom. I offer these suggestions to librarians who, with little or no instructional design education or experience, are faced with presenting information literacy instruction to groups of college students.

1) Teach often. Requests for library instruction usually come in waves during each semester, so there may be times when the opportunity to teach is plentiful and others when you will go a full week with few or no sessions at all. Ask the person who compiles instruction statistics at your library when the busy time is, and try to set aside an

\section{About the author}

Jeanine Akers is instructional service librarian at the University of Memphis, e-mail: jmakers@memphis.edu 
ample amount of time to volunteer to teach several sessions (many of you may not have to volunteer).

If you are teaching a great deal, especially if you are repeating the same class, you will be able to gauge what works and what you can cut. Early on, I spent a lot of time coming up with new ideas for teaching that I abandoned after trying only once. After teaching more often, I realized that new ideas deserve a few trials before being discarded.

One of the best things to happen for me as a teacher was instructing nine freshman seminar classes in one week. The concentration allowed me to test and re-test several ideas in a short period of time to discover what was effective and how formal or casual I could be, and to work out the timing of the session.

2) Learn and borrow from other librarians. Observe your colleague's instructional sessions. Look for things you can adopt or adapt into your own teaching, and look for things to avoid. Don't feel pressured to mimic their style or become intimidated by thinking that they are better in the classroom. Pay attention to what works for them and consider whether or not this is something you can add to your teaching.

Observe the students, too. What explanations elicit the best response from the students? At what point do they seem to get lost or bored? Using another librarian's technique entirely may result in a stiff or unnatural presentation, so borrow the successful components, but look for ways to make them your own.

3) Think like a student (take a class). Experience from the other side of the classroom can give you great insights into your teaching style. As a student, you can reflect on the aspects of the instructor's style that are most interesting and meaningful to you. Ask around about which professors are known for being particularly good on your campus and audit or enroll in one of their courses. Not only will you learn from studying their technique, you will also become more aware of what it is like to be a student at your college or university. This can help shape your instruction sessions, and troubleshoot problems, and it will give you an invaluable knowledge of your campus.

4) Think like teaching faculty (teach a credit-bearing class). If your school has an information literacy course for credit, offer to teach it or team-teach it one semester. If not, see if your campus has a freshman seminar and consider being an instructor in that program. This not only allows you to spread information literacy competencies to a larger student population, but you'll get to know more about students and more about yourself as a teacher. There is also a wealth of networking opportunities in teaching credit-bearing courses, and sometimes extra compensation.

5) Consider personality styles. Researchers have discovered that a majority of librarians have a preference for introversion, intuition, and thinking styles, while college freshman (usually the largest group to have information literacy instruction) often lean toward extroversion, sensing, and feeling. ${ }^{3}$ Structuring a class to communicate to a variety of styles can be difficult, but it is definitely worthwhile.

Don't be afraid to be yourself in front of the class. My personality is marked by both intuition and feeling preferences and the hardest thing for me was making a connection with the students I was teaching. Since I was only able to work with them for an hour to an hour and a half at a time, it was difficult for me to communicate with these students. Classes invariably went better when I knew a little bit about the students and their topics, which is not always possible in large classes. By breaking out of my shyness and asking students several questions up front, I am able to make a connection with them early in the session and feel more comfortable working personal anecdotes and humor into the presentation.

6) Learn about learning styles. Like personality styles, knowledge of the different ways people learn can also enhance your classroom presence. While some students will become immediately bored with a lecture, others will be asking you to repeat things and taking copious notes. While students with linear learning styles might prefer an outlined description of the research process, other students will want a big picture approach and will want to experiment with the 
process on their own. Develop your sessions

with all learning styles in mind, and try not to be offended if some students begin to try things differently than you originally outlined. Although it can be frustrating when students ask questions about something you explained moments ago, this is often a sign of a different learning style than your own, rather than of disrespect to your instruction.

7) Be patient with yourself. Even if you become a stellar teacher, there will inevitably be some classes that do not go as well as you'd like. There are numerous factors that influence the flow of a class over which you have little or no control. The professor's enthusiasm, knowledge, and relationship with the class have a huge impact on your instructional session. Technology, time of day, and a variety of other factors will also come into play.

Accept that not everything is always going to go well, and try not to let a bad session affect your morale or esteem.

Give yourself time to develop as a teacher. Consider the bad experiences as just that - experiences. Learn what you can from them and then move on to the next day and the next class. Don't be afraid to ask for input from the instructor and the students through formal and informal assessments, and be thick-skinned when you read or listen to their comments.

\section{Notes}

1. For a discussion of library instruction responsibilities in academic libraries and instruction librarian education see Lisa Janicke Hinchliffe, "Learning to Teach," Research Strategies 18 (2001): 251-252, and the subsequent article by Yvonne Nalani Meulemans and Jennifer Brown, "Educating instruction librarians: A model for library and information science education," Research Strategies 18 (2001): 253-264.

2. Instruction Section, Association of College and Research Libraries, American Library Association. "Library Instruction Courses Offered by ALA-Accredited Library Schools," 2002, www.calstatela.edu/library/bi/ckahl/isec /libraryschools.htm.

3. Mary Jane Scherdin and Anne K. Beaubien, "Shattering our stereotype: Librarians new image," Library Journal 120, no. 12 